\title{
PREMI ASURANSI JIWA PADA AKHIR TAHUN KEMATIAN DAN PADA SAAT KEMATIAN TERJADI
}

\author{
NOVA NOFRIDAWATI \\ Program Studi Matematika, \\ Fakultas Matematika dan Ilmu Pengetahuan Alam, Universitas Andalas Padang, \\ Kampus UNAND Limau Manis Padang, Indonesia \\ dyan_nova@yahoo.com
}

\begin{abstract}
Abstrak. Sebagai jaminan terhadap hilangnya penghasilan karena disebabkan oleh kematian, maka asuransi jiwa menyediakan berbagai produk yang bisa dipilih oleh masingmasing konsumen sesuai dengan kemampuan dan kebutuhannya. Diantaranya asuransi diskret dan asuransi kontinu. Perhitungan nilai premi atas berbagai produk dalam asuransi diskret dan asuransi kontinu dapat menunjukkan perbedaan pada masing-masing jenis produk juga umur pemegang polis.
\end{abstract}

Kata Kunci: Asuransi jiwa, premi asuransi, sistem pembayaran santunan asuransi, asuransi diskret, asuransi kontinu.

\section{Pendahuluan}

Kematian bisa terjadi pada siapa saja. Tidak ada yang bisa menjamin apa yang akan terjadi pada hidup setiap manusia. Jangankan untuk beberapa tahun kedepan, untuk semenit kedepan pun tidak ada yang dapat memprediksikannya. Karenanya untuk menghindari atau paling tidak meminimalkan resiko yang mungkin terjadi itulah, setiap orang membutuhkan sesuatu yang dapat menjamin kehidupan orangorang yang ia tinggalkan apabila sesuatu yang tidak diinginkan terjadi padanya. Cara yang bisa digunakan untuk menjaminnya adalah dengan menabung uang di bank, atau dengan mengikuti suatu asuransi jiwa.

Pada asuransi jiwa, besarnya santunan (claim) tergantung atas iuran (premi) masing-masing orang yang membeli produk asuransi tersebut, dan sesuai dengan perjanjian yang terdapat di dalam kontrak. Pada umumnya sistem pembayaran santunan asuransi ada 2 macam, yaitu pembayaran santunan pada saat kematian terjadi (asuransi kontinu) dan pembayaran santunan asuransi pada akhir tahun kematian polis (asuransi diskret). Pada tulisan ini dibahas kedua jenis sistem pembayaran tersebut dengan memberikan ilustrasi kasusnya masing-masing.

\section{Matematika Asuransi}

\subsection{Tabel Mortalitas}

Perusahaan asuransi mendasarkan perhitungannya pada Tabel Mortalitas. Tabel Mortalitas berisi peluang seseorang meninggal menurut umurnya. Secara sederhana, tabel mortalitas dapat diartikan sebagai tabulasi banyaknya orang yang hidup dan 
meninggal dari usia 0 sampai batas usia teratas, yaitu sampai batas usia dimana banyaknya orang pada usia tersebut adalah 0 orang.

Notasi $l_{0}$ melambangkan banyaknya orang yang lahir pada tahun tertentu. $l_{1}$ adalah mereka dari $l_{0}$ yang mencapai umur 1 tahun. $l_{2}$ adalah mereka dari $l_{1}$ yang mencapai umur 2 tahun. Begitu seterusnya hingga kita sampai pada definisi umum $l_{x}$, yaitu banyak orang yang hidup sampai pada umur $x$. Sedangkan jumlah orang yang meninggal dari $l_{x}$ orang sebelum mencapai usia $x+1$ dinyatakan dengan simbol $d_{x}$, yaitu

$$
d_{x}=l_{x}-l_{x+1} .
$$

Kemungkinan bahwa orang yang berusia $x$ akan bertahan hidup paling tidak 1 tahun, yaitu mencapai umur $x+1$ dituliskan sebagai berikut:

$$
p_{x}=\frac{l_{x+1}}{l_{x}}
$$

dan peluang seseorang berumur $x$ akan bertahan sampai umur $x+n$ dituliskan dalam bentuk

$$
{ }_{n} p_{x}=\frac{l_{x+n}}{l_{x}} .
$$

Untuk peluang seseorang yang berusia $x$ akan meninggal sebelum mencapai usia $x+1$, atau peluang seseorang yang berusia $x$ meninggal antara usia $x$ dan $x+1$ tahun dinyatakan dengan simbol $q_{x}$,

$$
q_{x}=1-p_{x}=1-\frac{l_{x+1}}{l_{x}}=\frac{l_{x}-l_{x+1}}{l_{x}}=\frac{d_{x}}{l_{x}}
$$

dan peluang seseorang yang beusia $x$ meninggal dalam kurun waktu n tahun ditulis

$$
{ }_{n} q_{x}=1-{ }_{n} p_{x}=1-\frac{l_{x+n}}{l_{x}}=\frac{l_{x}-l_{x+n}}{l_{x}} .
$$

Peluang seseorang yang berumur $x$ tahun akan bertahan untuk $n$ tahun berikutnya dan meninggal pada tahun ke $n+1$ ditulis dengan

$$
{ }_{n} \mid q_{x}=\frac{l_{x+n}-l_{x+n+1}}{l_{x}}
$$

dan peluang seseorang yang berumur $x$ akan mati diantara umur $x+n$ dan $x+n+m$ ditulis dengan

$$
\left.{ }_{n}\right|_{m} q_{x}=\frac{l_{x+n}-l_{x+n+m}}{l_{x}}[4] .
$$

\subsection{Simbol Komutasi}

Simbol komutasi ditulis untuk menyederhanakan penulisan persamaan matematika yang digunakan dalam asuransi, simbol komutasi yang digunakan antara lain:

$$
\begin{gathered}
D_{x}=v^{x} l_{x} \\
N_{x}=D_{x}+D_{x+1}+D_{x+2}+\cdots+D_{w}=\sum_{i=0}^{w} D_{x+i}
\end{gathered}
$$


Premi Asuransi Jiwa pada Akhir Tahun Kematian dan Pada Saat Kematian Terjadi 81

$$
\begin{gathered}
S_{x}=N_{x}+N_{x+1}+N_{x+2}+\cdots+N_{w}=\sum_{i=0}^{w} N_{x+i} \\
C_{x}=v^{x+1} d_{x} \\
M_{x}=C_{x}+C_{x+1}+C_{x+2}+\cdots+C_{w}=\sum_{i=0}^{w} C_{x+i} \\
R_{x}=M_{x}+M_{x+1}+M_{x+2}+\cdots+M_{w}=\sum_{i=0}^{w} M_{x+i} \\
\bar{C}_{x}=v^{x+1 / 2} d_{x} \\
\bar{M}_{x}=\bar{C}_{x}+\bar{C}_{x+1}+\bar{C}_{x+2}+\cdots+\bar{C}_{w}
\end{gathered}
$$

dimana $v=\frac{1}{1+i}=(1+i)^{-1}$, dengan $i$ merupakan tingkat bunga dalam setahun, dan $w$ merupakan usia tertinggi yang dicapai[4].

Dalam asuransi terdapat serangkaian pembayaran berkala dimana setiap pembayaran sebenarnya akan dilakukan hanya jika pemegang polis masih hidup pada saat pembayaran jatuh tempo, yang disebut sebagai anuitas hidup. Terdapat beberapa jenis sistem pembayaran tersebut, diantaranya :

1. Anuitas Dwiguna Murni

$$
{ }_{n} E_{x}=\frac{D_{x+n}}{D_{x}}
$$

2. Anuitas Seumur Hidup

$$
\text { Anuitas Akhir: } a_{x}=\frac{N_{x+1}}{D_{x}} \text {, Anuitas Awal: } \ddot{a}_{x}=\frac{D_{x}+N_{x+1}}{D_{x}}
$$

3. Anuitas Hidup Sementara/Berjangka

$$
\text { Anuitas Akhir: } a_{x: n\rceil}=\frac{N_{x+1}-N_{x+n+1}}{D_{x}} \text {, Anuitas Awal: } \ddot{a}_{x: n\rceil}=\frac{N_{x}-N_{x+n}}{D_{x}}
$$

4. Anuitas Hidup Tertunda $n$-tahun

$$
\text { Anuitas Akhir: }{ }_{n} \mid a_{x}=\frac{N_{x+n+1}}{D_{x}} \text {, Anuitas Awal: }{ }_{n} \mid \ddot{a}_{x}=\frac{N_{x+n}}{D_{x}}
$$

5. Anuitas Hidup Sementara Tertunda

$$
\begin{gathered}
\text { Anuitas Akhir: }\left.{ }_{n}\right|_{m} a_{x}=\frac{N_{x+n+1}-N_{x+n+m+1}}{D_{x}}, \\
\text { Anuitas Awal: }\left.{ }_{n}\right|_{m} \ddot{a}_{x}=\frac{N_{x+n}-N_{x+n+m}}{D_{x}}
\end{gathered}
$$

6. Anuitas Hidup Pembayaran $m$-kali Setahun

Anuitas Akhir: $a_{x}^{(m)}=a_{x}+\frac{m-1}{2 m}$, Anuitas Awal: $\ddot{a}_{x}^{(m)}=\ddot{a}_{x}+\frac{m-1}{2 m}[3]$.

Ketika frekuensi dari pembayaran $m$-kali menjadi tak hingga pada anuitas seumur hidup dengam pembayaran $m$-kali setahun, maka anuitas ini disebut anuitas kontinu[5].

1. Anuitas Kontinu Seumur Hidup 
Nova Nofridawati

$$
\bar{a}_{x}=\frac{\bar{N}_{x}}{\bar{D}_{x}}
$$

2. Anuitas Kontinu Sementara/Berjangka

$$
\bar{a}_{x: \bar{n}}=\frac{\bar{N}_{x}-\bar{N}_{x+n}}{D_{x}}[3] .
$$

\section{Sistem Pembayaran Santunan Asuransi Jiwa}

Sistem pembayaran santunan pada umumnya ada dua macam, yaitu pembayaran santunan pada saat kematian terjadi (asuransi kontinu) dan pembayaran santunan asuransi pada akhir tahun kematian polis (asuransi diskret).

\subsection{Asuransi Diskret (Pembayaran Santunan Asuransi Pada Akhir Tahun Kematian Polis)}

1. Asuransi Jiwa Seumur Hidup

$$
A_{x}=\frac{M_{x}}{D_{x}}=\frac{v N_{x}-N_{x+1}}{D_{x}}
$$

2. Asuransi Jiwa Berjangka/Sementara

$$
A_{x: n\rceil}^{1}=\frac{v\left(N_{x}-N_{x+n}\right)-N_{x+1}+N_{x+n+1}}{D_{x}}
$$

3. Asuransi Jiwa Dwiguna/Endowment

$$
A_{x: n\rceil}=\frac{v\left(N_{x}-N_{x+n}\right)-N_{x+1}+N_{x+n+1}+D_{x+n}}{D_{x}}[3] .
$$

\subsection{Asuransi Kontinu (Pembayaran Santunan Asuransi Pada} Saat Kematian Terjadi)

1. Asuransi Jiwa Seumur Hidup

$$
\bar{A}_{x}=\frac{\bar{M}_{x}}{D_{x}}
$$

2. Asuransi Jiwa Berjangka/Sementara

$$
\bar{A}_{x: n\rceil}^{1}=\frac{\bar{M}_{x}-\bar{M}_{x+n}}{D_{x}}
$$

3. Asuransi Jiwa Dwiguna/Endowment

$$
\bar{A}_{x: n\rceil}=\frac{\bar{M}_{x}-\bar{M}_{x+n}+D_{x+n}}{D_{x}}[3] .
$$

\section{Simulasi Premi Asuransi Jiwa yang Dibayarkan pada Akhir Tahun Kematian dan Pada Saat Kematian Terjadi}

Seorang pemuda ingin membeli produk asuransi sehingga ada yang menjamin keluarganya apabila sesuatu yang buruk terjadi padanya. Pemuda ini berumur 28 tahun dan ia menginginkan santunan yang diberikan kepada ahli warisnya nanti sebesar 
Premi Asuransi Jiwa pada Akhir Tahun Kematian dan Pada Saat Kematian Terjadi 83

Rp300.000.000,-. Produk-produk asuransi yang ditawarkan oleh perusahaan asuransi adalah asuransi jiwa seumur hidup, asuransi jiwa berkala/sementara, dan asuransi dwiguna. Akan ditentukan masing-masing premi tunggal bersih untuk pembayaran santunan dilakukan pada akhir tahun kematian polis dengan pembayaran santunan dilakukan pada saat kematian terjadi jika produk yang dipilih pria tersebut adalah:

a. Asuransi jiwa seumur hidup dengan masa pembayaran premi 10 tahun.

b. Asuransi jiwa berjangka/sementara dengan masa asuransinya 20 tahun.

\section{a. Asuransi jiwa seumur hidup dengan masa pembayaran premi 10 tahun.}

(1) Pembayaran santunan asuransi pada akhir tahun kematian polis (Asuransi Diskret).

Premi tunggal bersih

$$
\begin{gathered}
A_{x}=\frac{M_{x}}{D_{x}}=\frac{v N_{x}-N_{x+1}}{D_{x}} \\
\text { dimana } v=\frac{1}{(1+i)}=(1+i)^{-1}=(1+0.04)^{-1}=0.9615, \text { maka } \\
3.10^{8} \cdot A_{x}=3.10^{8} \frac{\left.(0.9615) N_{2} 8-N_{2}\right)}{D_{2} 8} \\
3.10^{8} \cdot A_{x}=3.10^{8} \frac{(0.9615)(628353)-(597583)}{30752} \\
=64175430.87
\end{gathered}
$$

Jadi, premi tunggal bersih (premi yang dibayarkan sekaligus) untuk seorang pria yang berusia 28 tahun adalah sebesar Rp64.175.431,-

(2) Pembayaran santunan asuransi pada kematian terjadi (Asuransi Kontinu).

Premi tunggal bersih

$$
\bar{A}_{x}=\frac{\bar{M}_{x}}{D_{x}}
$$

maka

$$
\bar{A}_{x}=\frac{\bar{M}_{x}}{D_{x}}=\frac{6715.922}{30752}=0.218
$$

akibatnya

$$
3.10^{8} \bar{A}_{x}=\left(3.10^{8}\right)(0.218)=65516928.98
$$

Jadi, premi tunggal bersih (premi yang dibayar sekaligus) untuk seorang pria yang berusia 28 tahun adalah Rp65.516.929,--

b. Asuransi jiwa berjangka/sementara dengan masa asuransinya 20 tahun.

(1) Pembayaran santunan asuransi pada akhir tahun kematian polis (Asuransi Diskret) 
Premi tunggal bersih

$$
\begin{aligned}
& A_{x: n\rceil}^{1}=\frac{v\left(N_{x}-N_{x+n}\right)-\left(N_{x+1}-N_{x+n+1}\right)}{D_{x}} \\
& \text { dimana } v=\frac{1}{(1+i)}=(1+i)^{-1}=(1+0.04)^{-1}=0.9615 \text { maka } \\
& 3.10^{8} \cdot A_{x: n\rceil}^{1}=\frac{v\left(N_{2} 8-N_{4} 8\right)-\left(N_{2} 9-N_{4} 9\right)}{D_{2} 8} \\
& =3.10^{8} \frac{(0.9615)(628335-201406)-(597583-188201)}{30752} \\
& =\left(3.10^{8}\right)(0.036)=10830841.9
\end{aligned}
$$

Jadi, premi tunggal bersih ( premi yang dibayarkan sekaligus) untuk seorang pria yang berusia 28 tahun adalah sebesar Rp10.830.842,--

(2) Pembayaran santunan asuransi pada kematian terjadi (Asuransi Kontinu) Premi tunggal bersih

$$
\begin{aligned}
\bar{A}_{x: n\rceil}^{1} & =\frac{\bar{M}_{x}-\bar{M}_{x+n}}{D_{x}}=\frac{\bar{M}_{2} 8-\bar{M}_{4} 8}{D_{2} 8} \\
& =\frac{6715.922-5566.708}{30752}=11211114.72
\end{aligned}
$$

Jadi, premi tunggal bersih (premi yang dibayar sekaligus) untuk seorang pria yang berusia 28 tahun adalah Rp11.211.115,--

Maka dari simulasi kasus yang sudah dilakukan, didapatkan nilai premi tunggal bersihnya yang berbeda pada masing-masing sistem pembayaran santunannya. Nilai premi asuransi pada setiap sistem pembayaran santunan asuransi yang dibayarkan pada akhir tahun kematian (diskret) akan lebih kecil dibandingkan dengan nilai premi untuk sistem pembayaran santunan asuransi yang dibayarkan pada saat kematian terjadi (kontinu). Hal ini disebabkan karena jangka waktu pembayaran untuk premi tunggal bersih diskret lebih lama daripada jangka waktu pembayaran untuk premi tunggal bersih kontinu.

\section{Kesimpulan}

Sistem pembayaran santunan asuransi pada umumnya ada dua macam, yaitu pembayaran santunan pada saat kematian terjadi (asuransi kontinu) dan pembayaran santunan asuransi pada akhir tahun kematian polis (asuransi diskret).

Dari setiap sistem pembayaran santunan asuransi, masing-masingnya memiliki nilai premi yang berbeda. Perbedaan ini dikarenakan perbedaan jangka waktu pembayaran antara premi untuk asuransi diskret dan kontinu yang berbeda.

\section{Ucapan Terima Kasih}

Penulis mengucapkan terima kasih kepada Bapak Dodi Devianto, Bapak Yudiantri Asdi, Ibu Izzati Rahmi HG, Ibu Lyra Yulianti, dan Ibu Riri Lestari yang telah memberikan masukan dan saran sehingga paper ini dapat diselesaikan dengan baik. 
Premi Asuransi Jiwa pada Akhir Tahun Kematian dan Pada Saat Kematian Terjadi 85

\section{Daftar Pustaka}

[1] Bowers, N. JR. 1997. Actuarial Mathematics. The Society of Actuaries, USA

[2] Catarya, I. 1988. Materi Pokok Asuransi II. Cetakan pertama. Karunika, Universitas Terbuka, Jakarta

[3] Jordan, C. W. 1991. Life Contingencies. The Society of Actuaries, USA

[4] Larson, R. E. 1962. Life Insurance Mathematics. Cetakan keempat. John Wiley \& Sons, Inc, London

[5] Takashi, F. 1993. Matematika Asuransi Jiwa Bagian I. Incoporated Foundation OLICD Center, Tokyo 